\title{
Buck Semen Does Not Easily Succumb to Oxidative Stress
}

\author{
Cyril Mpho Pilane ${ }^{*}$, Malebogo Audrey Bopape², Bovula Ntombizodwa1,3, \\ Mohleko Helen Mapeka ${ }^{1}$
}

\footnotetext{
${ }^{1}$ Agricultural Research Council, Animal Production Campus, Germplasm Conservation \& Reproductive Biotechnologies, Irene, South Africa

${ }^{2}$ Department of Biological and Agricultural Sciences, Sol Plaatjie University, Kimberly, South Africa

${ }^{3}$ Department of Agricultural, Earth and Environmental Science, Animal and Poultry Science, University of KwaZulu-Natal, Scottsville, South Africa

Email: *cyril@arc.agric.za
}

How to cite this paper: Pilane, C.M., Bopape, M.A., Ntombizodwa, B. and Mapeka, M.H. (2019) Buck Semen Does Not Easily Succumb to Oxidative Stress. Open Journal of Animal Sciences, 9, 65-75.

https://doi.org/10.4236/ojas.2019.91006

Received: November 6, 2018

Accepted: January 1, 2019

Published: January 4, 2019

Copyright (C) 2019 by authors and Scientific Research Publishing Inc. This work is licensed under the Creative Commons Attribution International License (CC BY 4.0).

http://creativecommons.org/licenses/by/4.0/ (c) (i) Open Access

\begin{abstract}
Semen processing and manipulation generally result in loss of sperm motility and sperm velocity due in part to oxidative stress. In this study we investigated the vulnerability of South African indigenous unimproved buck semen to oxidative stress induced by an oxidative stress inducing agent, namely, hydrogen peroxide $\left(\mathrm{H}_{2} \mathrm{O}_{2}\right)$. Semen ejaculates were collected from four superior South African indigenous unimproved bucks in a total of ten collections and then each duplicate was treated with different concentrations of $\mathrm{H}_{2} \mathrm{O}_{2}$ in presence or absence of Dithiothreitol (DTT). Sperm motility and velocities were determined using the computer aided sperm class analyser (CASA). SYBR-14 and propidium iodide (PI) Live/Dead assay kit was used to determine cell viability and Yo-Pro-1 plus PI Apoptosis kit was used to determine apoptosis. Statistical analysis was performed on the data using SPSS version 17.0 for Windows (SPSS Inc., Chicago, IL). South African indigenous unimproved buck raw semen motility was between $97 \%$ with $98 \%$ viability and $0 \%$ apoptotic cells. Comparisons of the untreated controls at 0 and $3 \mathrm{hrs}$ incubations revealed that after $3 \mathrm{hrs}$ there was overall a decrease in the number viable cells with the majority of remaining cells exhibiting circular movements accompanied by high progressive (PM) and rapid (RAP) motilities. In treated South African indigenous unimproved buck semen, $\mathrm{H}_{2} \mathrm{O}_{2}$ marginally increased total motility (TM) with few apoptotic sperm cells while retaining high viability. Also, $\mathrm{H}_{2} \mathrm{O}_{2}$ increased straight line distances travelled of more than 4 fold as compared to untreated controls with no circularly moving cells. Moreover, inclusion of DTT, an antioxidant, had minimal effects on TM, RAP, curvilinear velocity (VCL), straight line velocity (VSL), linearity (LIN)
\end{abstract}


and wobble (WOB) but positively affected PM, average path velocities (VAP), apoptosis and viability. Our Pearson's correlation data revealed that only straightness (STR) was highly positively affected by $\mathrm{H}_{2} \mathrm{O}_{2}$. Overall, the South African indigenous unimproved buck semen resisted deterioration in TM, RAP, VCL, VAP, VSL, LIN, WOB, viability and apoptosis under oxidative stress conditions. These data suggest that the South African indigenous unimproved buck semen does not easily succumb to oxidative stress.

\section{Keywords}

South African Indigenous Bucks, Oxidative Stress, Motility, Semen

\section{Introduction}

There is growing interest in the cryopreservation of the buck semen worldwide [1] [2]. Cryopreservation is the technique of freezing cells and tissues at very low temperatures at which the biological material remains genetically stable but metabolically inert. In South Africa, cryopreservation of gametes from indigenous breeds has been recognised as a national priority due to their superior traits that are suitable for the local conditions [3] [4]. In particular, the South African indigenous unimproved bucks are currently enjoying maximum attention as they have been previously ignored [5] [6].

Previously published data indicates that raw semen from this breed has TM above $83 \%$, high PM, and high RAP accompanied by high viability [5]. Accompanying these features were high VAP, LIN, STR and WOB, characteristic of superior quality semen [5]. These experiments have also revealed that following cryopreservation, the South African indigenous unimproved buck semen showed decreased TM to less than 40\% with low PM and RAP, accompanied by lower VAP, LIN, STR and WOB, indicating deterioration of semen quality [5].

Hydrogen peroxide $\left(\mathrm{H}_{2} \mathrm{O}_{2}\right)$ is often used as an experimental source of oxygen-derived free radicals such as superoxide radical $\left(\mathrm{O}^{2-}\right.$.) and hydroxyl radical $(\mathrm{OH})$ which induces oxidative stress [7]. Oxidative stress has been implicated as the main culprit for the decreased semen motility and semen velocity parameters in males leading to infertility [8]. However, a cocktail of antioxidants can effectively improve semen parameters in infertile males [9]. Other studies have indicated that the addition of antioxidants to cryopreservation medium can improve post-thaw sperm quality [10], while other antioxidants, mainly thiols, like DTT can prevent $\mathrm{H}_{2} \mathrm{O}_{2}$ mediated loss of sperm motility [11].

Our previously published data indicated that in boars, the semen motility and semen velocity parameters were compromised under $\mathrm{H}_{2} \mathrm{O}_{2}$ induced oxidative stress in the presence or absence of an anti-oxidant like DTT [12]. Notably, TM, PM, RAP plus VAP, LIN, STR and WOB were all drastically decreased under oxidative stress, irrespective of the presence or absence of an antioxidants like DTT. The decreases in these parameters, accompanied by high rate of sperm cell 
death via apoptosis and decreased viability, indicated that boar semen is highly susceptible to oxidative stress and DTT fail to rescue them [12]. We have also shown recently that other antioxidants like $\alpha$-tocopherol, taurine and cysteine do not restore boar semen motility and velocity parameters following oxidative stress associated with liquid preservation [13]. Others have shown that post-thaw buck semen exhibited decreased DNA damage and lipid peroxidation accompanied by increased antioxidant enzyme activities with no changes in progressive motilities and sperm velocity parameters in the presence of antioxidants [14].

The South African unimproved buck semen has never been directly exposed to an oxidative stress inducing agent to test their susceptibility to oxidative stress. Hence, this study was conducted to assess whether the South African unimproved buck semen can easily succumb to oxidative stress induced by $\mathrm{H}_{2} \mathrm{O}_{2}$, in the presence or absence of an antioxidant like DTT.

\section{Materials and Methods}

The study was conducted at the Small Stock Research Unit of Agricultural Research Council, Germplasm Conservation \& Reproductive Biotechnologies Unit, Irene, South Africa. The Agricultural Research Council-Irene campus is located at $25^{\circ} 55^{\prime}$ South; $28^{\circ} 12^{\prime}$ East. The institute is located in the Highveld region of South Africa and situated at an altitude of 1525 meters above sea level. Four superior South African indigenous bucks were stratified based on age (2 years) and weight $(25-45 \mathrm{~kg})$. The South African indigenous unimproved bucks were in good health condition throughout the duration of the study. This study was carried out in strict accordance with the recommendations in the Guide for the Care and Use of Animals under the guidelines of the Agricultural Research Council, Animal Production Institute Animal Ethics Committee (APIEC2011/38). Water was given ad libitum throughout the duration of the study.

\subsection{Bucks Semen Collection and Processing}

Semen was collected from four South African indigenous unimproved bucks using an electro-ejaculator, each with a total of ten collections. After collections, the semen samples were placed into the thermo-flask at $37^{\circ} \mathrm{C}$ and transported to the laboratory. In the laboratory semen evaluations were performed within $1 \mathrm{~h}$. Semen volume was measured by using the graduated falcon tube, $\mathrm{pH}$ was measured using the $\mathrm{pH}$ meter (Oaklon, EW35614-30, Cole-Parmer, USA), the sperm concentration was measured using the spectrophotometer (Jenway $6310 \mathrm{spec}-$ trophotometer, Bibby Scientific, England), the semen motility rates were assessed using the CASA system (Sperm Class Analyzer ${ }^{\circledR}$ [SCA] 5.0, Microptic, Barcelona, Spain), semen viability and apoptosis were evaluated using the SYBR/PI live/dead kit (Invitrogen, Molecular probes, USA) and Yo-Pro-1/PI apoptosis kit (Invitrogen, Molecular probes, USA) respectively.

\subsection{Treatments}

For semen treatment, $\mathrm{H}_{2} \mathrm{O}_{2}$ stock solution was prepared in pre-warmed BO-Wash 
medium and kept at $4^{\circ} \mathrm{C}$ until use. During the experiment, semen at equal concentration and volume was treated with pre-warmed $\mathrm{H}_{2} \mathrm{O}_{2}$ stock to make 0,5 $\mu \mathrm{M}, 50 \mu \mathrm{M}$ and $200 \mu \mathrm{M}$ concentrations in pre-warmed BO-Wash medium. The treated semen samples were then incubated at $37^{\circ} \mathrm{C}$ for three hours in a humidified $5 \% \mathrm{CO}_{2}$ and $95 \%$ atmospheric air incubator (Sanyo, Japan). After three hours the samples were evaluated for total motility, progressive motility, rapid motility, semen velocities, sperm cell viability and sperm cell apoptosis.

\subsection{Sperm Motility Rate}

About $10 \mu \mathrm{l}$ of raw semen were placed into $500 \mu \mathrm{l}$ of BO-Wash medium in $15 \mathrm{ml}$ tube (Falcon ${ }^{\circledR} 352099$, USA). The tube was then kept in $\mathrm{CO}_{2}$ incubator (Sanyo, Japan) adjusted to $39^{\circ} \mathrm{C}$. Five micro litres of semen was placed on the warm glass slide $(\sim 76 \times 26 \times 1 \mathrm{~mm}$, Germany) and placed with a warmed cover slip $(22 \times 22$ $\mathrm{mm}$, Germany) over the microscope-warm plate (Omron) adjusted at $39^{\circ} \mathrm{C}$. The sperm motility rates were evaluated by computer assisted sperm analysis system (Sperm Class Analyzer ${ }^{\circledR}$ [SCA] 5.0, CASA, Microptic, Barcelona, Spain) at the 10× magnification (Nikon, China). The semen TM, PM, RAP and semen velocity parameters were then determined.

\subsection{Viability Assay}

For cell viability, SYBR-14 and PI Live/Dead kit was used and the cells were treated according to the manufacturer's recommendation (Invitrogen, Molecular probes, USA). Briefly, $50 \mu \mathrm{l}$ of semen was diluted with pre-warmed BO-Wash to $1 \mathrm{ml}$ and $5 \mu \mathrm{l}$ of a 50 times diluted SYBR-14 was added to the cells followed by incubation at $37^{\circ} \mathrm{C}$ for 10 minutes. After 10 minutes, $5 \mu \mathrm{l}$ of PI was added to the cells followed by incubation for another 10 minutes. After 10 minutes $5 \mu$ of cells was immediately placed on pre-warmed glass slide and observed under a fluorescent microscope at 10× magnifications (Olympus, model BX51). For this analysis, viable cells appeared green in colour while non-viable cells appeared red in colour. The percent cell viability was determined by counting the number of green cells out of three hundred cells in a field, divided by three. A correlation was then established between viability and $\mathrm{H}_{2} \mathrm{O}_{2}$ treatment in the presence or absence of DTT.

\subsection{Apoptosis Assay}

To determine cell apoptosis, cells were treated with the Yo-Pro-1/PI staining kit solutions according to the manufacturer's recommendations (Invitrogen, Molecular probes, USA). In brief, cells were treated with $5 \mu$ of Yo-Pro-1 and PI at the same time and incubated for 10 minutes. After incubation, $5 \mu$ of the stained cells was placed on a slide and viewed under a fluorescent microscope at $60 \times$ magnification (Olympus, model BX51). Four populations of cells were obtained, the light green or clear (live cells), the dark green (apoptotic cells), and red (dead/necrotic cells) and the red plus green cells (dead cells). The percent cell 
apoptotic cells were determined by counting the number of dark green cells out of three hundred cells in a field. A correlation was then established between the apoptosis and $\mathrm{H}_{2} \mathrm{O}_{2}$ treatment in the presence or absence of DTT.

\subsection{Data Analysis}

Pearson's correlation coefficients were calculated to test the relationship between the motility and velocity rates parameters, namely, TM, PM, RAP, VCL, VSL, VAP, LIN, STR, WOB, apoptosis and viability against the treatments. Data were examined using the Kolmogorov-Smirnov test to determine their distribution, a multivariate analysis of variance was performed (ANOVA) and when significant differences were found, and the non-parametric Mann-Whitney U-test was used to compare pairs of values directly if data did not adjust to a normal distribution. All analyses were performed using SPSS version 17.0 for Windows (SPSS Inc., Chicago, IL). Significance was set at $\mathrm{p}<0.05$.

\section{Results}

The analysis of the sperm motility and velocity parameters, by definition, gives an excellent insight into the sperm quality profile (Table 1 ). The raw semen obtained from the South African indigenous unimproved bucks showed an average sperm concentration of $0.876 \pm 321.55 \times 10^{9}$ cells $/ \mathrm{ml}$, with a $\mathrm{pH}$ of $7.5 \pm 0.5$, viability of $98 \pm 1.5$ and no apoptotic spermatozoa (Table 2 ). The analysed sperm quality profile of this raw semen revealed the percentage TM value of $97.0 \pm 3.95$, PM of $29.3 \pm 1.3$ and RAP of $8.37 \pm 8.01$ accompanied by VCL of $70.3 \pm 1.56$, VSL of $30.83 \pm 4.32$, VAP of $44.0 \pm 7.21$ and LIN plus STR of $64.6 \pm 5.32$ and $67.73 \pm 5.28$, respectively (Table 3 ).

The analysis of sperm cell viability using the SYBR-14/PI revealed a clear distinction between the viable and non-viable cells, with viable cells fluorescing

Table 1. Definitions of the sperm motility and velocity parameters.

\begin{tabular}{clc}
\hline Parameter & \multicolumn{1}{c}{ Definition } & Unit \\
\hline Total Motility (TM) & Percent of sperm showing any movement & $\%$ \\
Progressive Motility (PM) & Percent of sperm moving rapidly and in a straight path & $\%$ \\
Rapid Motility (RAP) & Percent of sperm travelling at a speed of $25 \mu \mathrm{m} / \mathrm{sec}$ or faster & $\%$ \\
Curvilinear Velocity (VCL) & Time-average velocity of sperm head along its actual path & $\mu \mathrm{m} / \mathrm{s}$ \\
Straight Line Velocity (VSL) & $\begin{array}{l}\text { Time-average velocity of sperm head projected along straight } \\
\text { line }\end{array}$ & $\mu \mathrm{m} / \mathrm{s}$ \\
Average Path Velocity & Time-average velocity of sperm head projected along its spatial & $\mu \mathrm{m} / \mathrm{s}$ \\
(VAP) & trajectory & Ratio of projected length to total length of curvilinear \\
Linearity (LIN) & trajectory; LIN = VSL/VCL & $\%$ \\
Straightness (STR) & $\begin{array}{l}\text { Ratio of projected length to average velocity of sperm head } \\
\text { along a spatial trajectory, STR = VSL/VAP }\end{array}$ & $\%$ \\
& $\begin{array}{l}\text { Expression of the degree of oscillation of the curvilinear path } \\
\text { about its spatial average path; WOB = VAP/VCL }\end{array}$ & $\%$ \\
\hline
\end{tabular}


Table 2. South African indigenous unimproved buck raw semen viability, apoptosis and macroscopic evaluations represented as mean \pm SD.

\begin{tabular}{|c|c|c|c|c|c|}
\hline Raw semen & $\begin{array}{c}\text { Concentration } \\
\left(1 \times 10^{9} \text { sperm cells } / \mathrm{ml}\right)\end{array}$ & $\mathrm{pH}$ & Volume (ml) & Viability (\%) & Apoptosis (\%) \\
\hline Buck & $0.876 \pm 321.55^{\mathrm{a}}$ & $7.5 \pm 0.5^{\mathrm{a}}$ & $0.45 \pm 0.20^{\mathrm{a}}$ & $98.5 \pm 1.5^{\mathrm{a}}$ & $0.00^{\mathrm{a}}$ \\
\hline
\end{tabular}

${ }^{a}$ Values with different subscripts with the same column differ significantly $(\mathrm{p} \leq 0.05)$.

Table 3. The motility and velocity rates of the South African indigenous unimproved buck raw semen represented as mean \pm SD.

\begin{tabular}{ccccccccc}
\hline TM\% & PM\% & RAP\% & VCL $(\mu \mathrm{m} / \mathrm{s})$ & VSL $(\mu \mathrm{m} / \mathrm{s})$ & VAP $(\mu \mathrm{m} / \mathrm{s})$ & LIN\% & STR\% & WOB\% \\
\hline $97.0 \pm 3.95^{\mathrm{a}}$ & $29.3 \pm 1.3^{\mathrm{b}}$ & $8.37 \pm 8.01^{\mathrm{a}}$ & $70.3 \pm 1.56^{\mathrm{b}}$ & $30.83 \pm 4.32^{\mathrm{a}}$ & $44.0 \pm 7.21^{\mathrm{a}}$ & $64.6 \pm 5.32^{\mathrm{a}}$ & $67.73 \pm 5.28$ & $63.5 \pm 0.5^{\mathrm{b}}$ \\
\hline
\end{tabular}

${ }^{\mathrm{a}, \mathrm{b}}$ Values with different subscripts with the same column differ significantly $(\mathrm{p} \leq 0.05)$.

green due to SYBR-14 absorption and non-viable cells absorbing SYBR-14 and $\mathrm{PI}$ and appearing as dominant red fluorescence (Figure 1). The class distribution of sperm cells according to average speed and distance travelled indicated untreated controls at $0 \mathrm{hrs}$ and $3 \mathrm{hrs}$ revealed a decrease in the number of motile cells as the viability decreased (Figure 2). At 0 hrs the RAP and PM motilities appears to be dominant however, after $3 \mathrm{hrs,} \mathrm{NPM} \mathrm{become} \mathrm{dominant} \mathrm{with} \mathrm{more}$ cells moving in circles or semi-circles (Figure 2) This class distribution of sperm cells according to average speed and distance travelled also revealed that while the $\mathrm{H}_{2} \mathrm{O}_{2}$ treatment decreased the overall number of viable cells, the progressive and rapid motilities remained high accompanied by the elimination of circular moving cells as compared to untreated controls (Figure 3). After $3 \mathrm{hrs}$ of incubation, DTT, $\mathrm{H}_{2} \mathrm{O}_{2}$ and $\mathrm{H}_{2} \mathrm{O}_{2}$ plus DTT appeared to activate sperm cells to travel longer distances in excess of $100 \mu \mathrm{m}$ as compared to untreated controls (Figure 3). Interestingly, all $\mathrm{H}_{2} \mathrm{O}_{2}$ concentrations used increased TM, but $50 \mu \mathrm{M} \mathrm{H}_{2} \mathrm{O}_{2}$ increased both TM and RAP in the presence of DTT (Figure 3, Table 4).

The untreated control semen had $\mathrm{TM}=50.0 \pm 33.1, \mathrm{PM}=43.6 \pm 1.3$ and RAP $=21.6 \pm$ 5.1. Treatment with $\mathrm{H}_{2} \mathrm{O}_{2}$ revealed that $50 \mu \mathrm{M} \mathrm{H}_{2} \mathrm{O}_{2}$ decreased PM $(29.95 \pm 1.95)$ and RAP $(23.7 \pm 12)$ but increased TM (68.8 \pm 5.75$) .200 \mu \mathrm{M}$ $\mathrm{H}_{2} \mathrm{O}_{2}$ also decreased RAP $(12.8 \pm 1.1)$ and PM $(32.95 \pm 11.05)$ with no changes in TM (56.85 \pm 3.85$)$ (Table 3). Also, in the presence of DTT, only $50 \mu \mathrm{M} \mathrm{H}_{2} \mathrm{O}_{2}$ increased PM (from $29.95 \pm 1.95$ to $42.8 \pm 1.5$ ) and RAP (from $11.7 \pm 9.6$ to 23.7 \pm 12.0 ) while $200 \mu \mathrm{M} \mathrm{H}_{2} \mathrm{O}_{2}$ increased $\mathrm{PM}$ (from $32.95 \pm 11.05$ to $57.17 \pm 15.92$ ) and decreased TM (from $56.85 \pm 3.85$ to $37.4 \pm 24.9$ ) with no change in RAP (from $12.8 \pm 1.1$ to $12.6 \pm 10.1$ ) (Table 3). The TM Pearson's correlation coefficient with $\mathrm{H}_{2} \mathrm{O}_{2}$ concentration remained low in the presence $(-0.0719)$ or absence (0.182) of DTT, while in the presence of DTT, PM Pearson's correlation improved from $\mathrm{r}=0.104$ to $\mathrm{r}=0.752$ and the RAP correlation changed from moderate but negative correlation $(-0.557)$ to low positive correlation $(0.0477)$ (Table 4).

Interestingly, $\mathrm{H}_{2} \mathrm{O}_{2}$ increased LIN $(24.89 \pm 2.86)$ significantly at $5 \mu \mathrm{M}, 50 \mu \mathrm{M}$ and $200 \mu \mathrm{M} \mathrm{H}_{2} \mathrm{O}_{2}$ to $67.25 \pm 13.15,65.05 \pm 11.45$, and $68.35 \pm 9.15$ respectively 


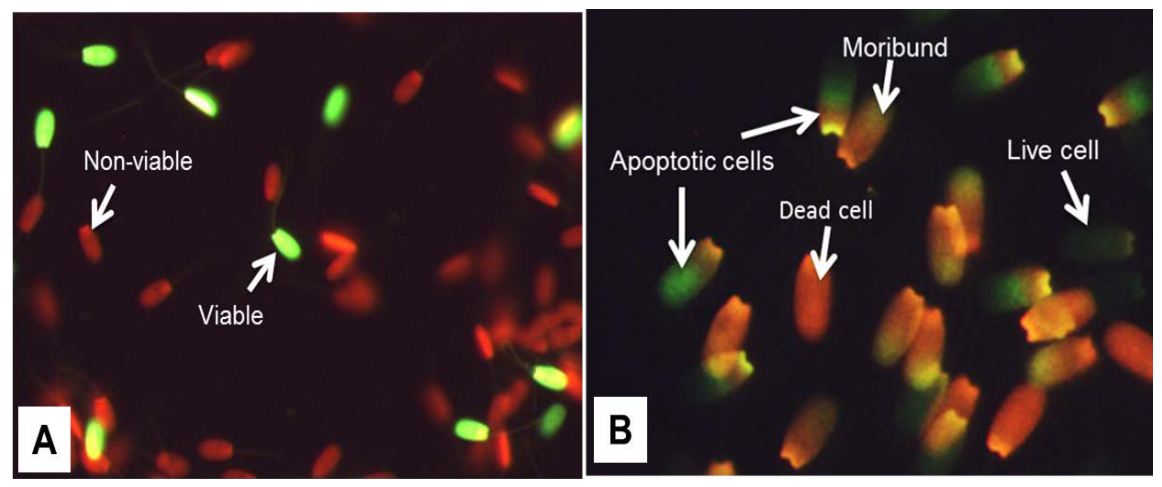

Figure 1. (A) The SYBR-14/PI cell viability staining of buck semen where red fluorescence represent non-viable sperm cells and green fluorescence represent viable sperm cells (10× magnification); (B) The Yo-Pro-1/PI apoptosis staining of buck semen showing apoptotic sperm cells in green fluorescence, moribund/dying sperm cells with dual fluorescence, dead sperm cells in red fluorescence while live cells had clear/light green fluorescence $(60 \times$ magnification).
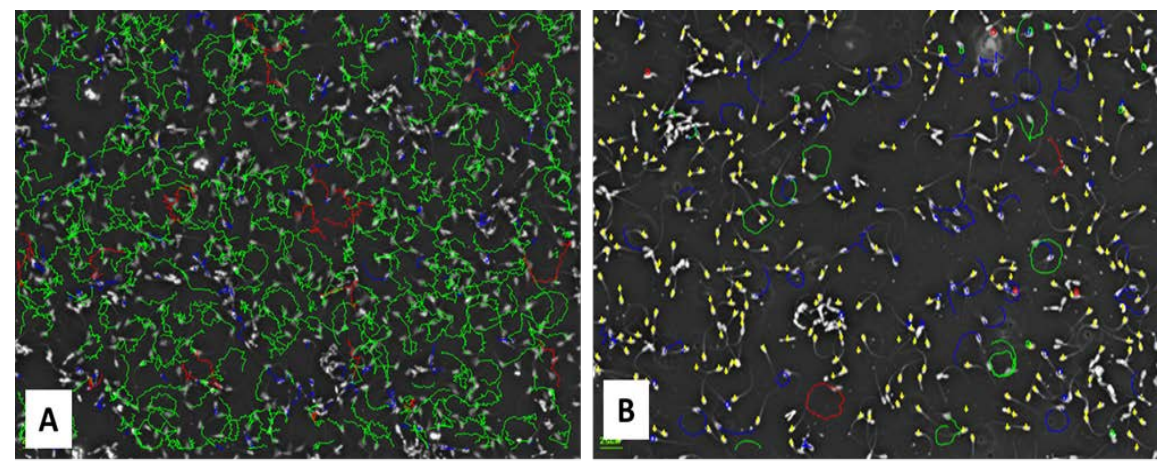

Figure 2. The class distribution of sperm cells according to their average speed showing the rapidly moving spermatozoa (RAP, red), Progressive motility (PM, green), Non-progressive motility (NPM, blue) and static (yellow) for untreated controls at (A) 0 hrs and (B) $3 \mathrm{hrs}$, bar $=25 \mu \mathrm{m}$.

Table 4. The sperm motility and velocity rates of treated South African indigenous unimproved buck semen represented as mean \pm SD.

\begin{tabular}{|c|c|c|c|c|c|c|c|c|c|}
\hline & $\% \mathrm{TM}$ & $\% \mathrm{PM}$ & $\%$ RAP & $\operatorname{VCL}(\mu \mathrm{m} / \mathrm{s})$ & $\operatorname{VSL}(\mu \mathrm{m} / \mathrm{s})$ & $\operatorname{VAP}(\mu \mathrm{m} / \mathrm{s})$ & $\%$ LIN & $\%$ STR & $\%$ WOB \\
\hline c & $0 \pm$ & 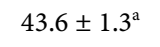 & 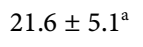 & $5^{\mathrm{a}}$ & $37.7 \pm$ & $2.5^{\mathrm{a}}$ & $24.8 \pm 2.86^{\mathrm{a}}$ & $73.2 \pm 8.87^{\mathrm{a}}$ & 68.43 \\
\hline $5 \mu \mathrm{M} \mathrm{H}_{2} \mathrm{O}_{2}$ & $8 \pm 14.0^{\mathrm{a}}$ & $41.1 \pm 0.9^{\mathrm{a}}$ & $16.15 \pm 5^{\mathrm{a}}$ & $86.6 \pm 17.7^{\mathrm{a}}$ & $60.5 \pm 23.5^{\mathrm{a}}$ & $75.8 \pm 20.5^{\mathrm{a}}$ & $67.2 \pm 13.1^{\mathrm{b}}$ & $77.25 \pm 9.75^{\mathrm{a}}$ & $86.3 \pm 6.12^{\mathrm{a}}$ \\
\hline $50 \mu \mathrm{M} \mathrm{H}_{2} \mathrm{O}_{2}$ & $8 \pm$ & $29.95 \pm 1.9^{\mathrm{b}}$ & $11.7 \pm 9.6^{\mathrm{a}}$ & $75.05 \pm$ & $49.3 \pm 11.4^{\mathrm{a}}$ & $63.6 \pm 17.8^{\mathrm{a}}$ & $65.0 \pm 11$ & 77.25 & 83.5 \\
\hline $200 \mu \mathrm{M} \mathrm{H}_{2} \mathrm{O}_{2}$ & $56.85 \pm 3.8^{\mathrm{a}}$ & $32.9 \pm 11.0^{\mathrm{b}}$ & $12.8 \pm 1.1^{\mathrm{b}}$ & $8.6 \pm 9.3^{\mathrm{a}}$ & $52.7 \pm 0.7^{\mathrm{a}}$ & $66.4 \pm 4.65^{\mathrm{a}}$ & $68.3 \pm 9.15^{\mathrm{b}}$ & 79. & $5^{\mathrm{a}}$ \\
\hline DTT & $47.0 \pm 20.3^{\mathrm{a}}$ & $41.15 \pm 1.1^{\mathrm{a}}$ & $12.7 \pm 8.9^{\mathrm{a}}$ & $82.4 \pm 6.21^{\mathrm{a}}$ & $46.0 \pm 21.4^{\mathrm{a}}$ & $66.8 \pm 15.9^{\mathrm{a}}$ & $54.3 \pm 21.9^{\mathrm{b}}$ & $65.2 \pm 17.08^{\mathrm{a}}$ & $80.1 \pm 13.97^{\mathrm{a}}$ \\
\hline $5 \mu \mathrm{M} \mathrm{H}_{2} \mathrm{O}_{2}+\mathrm{DTT}$ & $31.9 \pm 5.1^{\mathrm{a}}$ & $15.3 \pm 1.3^{\mathrm{c}}$ & $8.4 \pm 5.4^{\mathrm{a}}$ & $85.45 \pm 5.1^{\mathrm{a}}$ & $55.2 \pm 12^{\mathrm{a}}$ & $74.7 \pm 8.53^{\mathrm{a}}$ & $64.1 \pm 11.6^{\mathrm{b}}$ & $72.18 \pm 8.6^{\mathrm{a}}$ & $87.2 \pm 6.78^{\mathrm{a}}$ \\
\hline $50 \mu \mathrm{M} \mathrm{H}_{2} \mathrm{O}_{2}+\mathrm{DTT}$ & $70.35 \pm 9.9^{\mathrm{a}}$ & $42.8 \pm 1.5^{\mathrm{a}}$ & $23.7 \pm 12^{\mathrm{a}}$ & $70.2 \pm 6.2^{\mathrm{a}}$ & $23.5 \pm 8.7^{\mathrm{a}}$ & $51.0 \pm 11.6^{\mathrm{a}}$ & $33.1 \pm 11.9^{\mathrm{a}}$ & $44.53 \pm 11$ & $72.20 \pm 1$ \\
\hline $200 \mu \mathrm{M} \mathrm{H}_{2} \mathrm{O}_{2}+\mathrm{DTT}$ & $37.4 \pm 24.9^{\mathrm{a}}$ & $57.17 \pm 15.9^{\mathrm{a}}$ & $12.6 \pm 10^{\mathrm{a}}$ & $65.1 \pm 15.4^{\mathrm{a}}$ & $71.8 \pm 14.0^{\mathrm{a}}$ & $89.7 \pm 3.85^{\mathrm{a}}$ & $71.8 \pm 14.0^{\mathrm{b}}$ & $86.8 \pm 3.92^{\mathrm{a}}$ & $89.75 \pm 3.85^{\mathrm{a}}$ \\
\hline
\end{tabular}

$\mathrm{a}, \mathrm{b}, \mathrm{V}$ Values with different subscripts with the same column differ significantly $\mathrm{p} \leq 0.05$ ).

while the other semen velocity parameters of treated semen were not significantly different from their corresponding untreated controls (Table 3). In the 

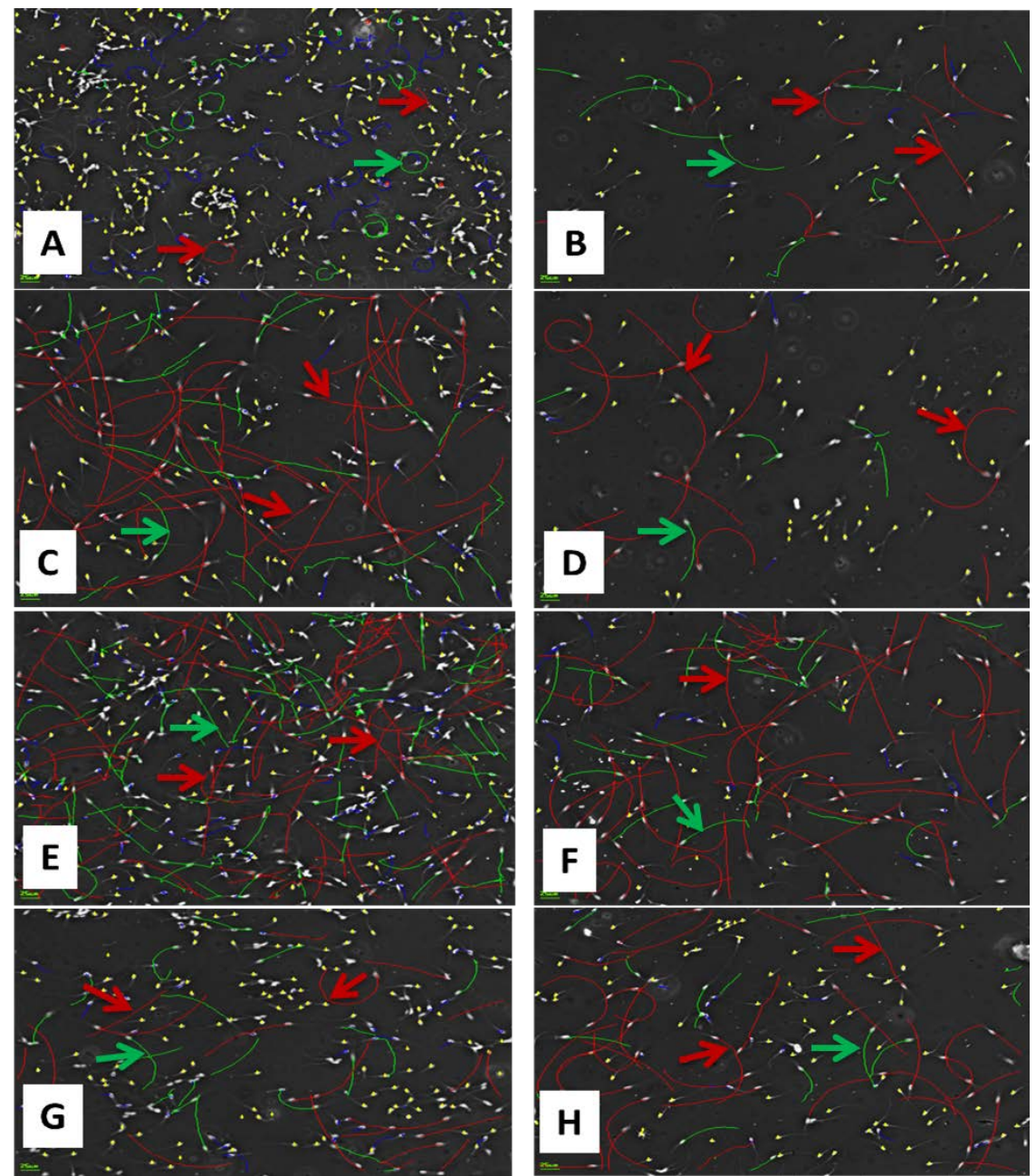

Figure 3. The class distribution of sperm cells according to their average speed showing the rapidly moving spermatozoa (RAP, red), Progressive motility (PM, green), Non-progressive motility (NPM, blue) and static (yellow). Sperm cells were treated for $3 \mathrm{hrs}$ (A) Untreated controls; (B) $5 \mu \mathrm{M}$ DTT; (C) $5 \mu \mathrm{M} \mathrm{H}_{2} \mathrm{O}_{2}$; (D) $5 \mu \mathrm{M} \mathrm{H}_{2} \mathrm{O}_{2}$ plus $5 \mu \mathrm{M}$ DTT; (E) $50 \mu \mathrm{M}$ $\mathrm{H}_{2} \mathrm{O}_{2}$; (F) $50 \mu \mathrm{M} \mathrm{H}_{2} \mathrm{O}_{2}$ plus $5 \mu \mathrm{M}$ DTT, (G) $200 \mu \mathrm{M} \mathrm{H}_{2} \mathrm{O}_{2}$; (H) $200 \mu \mathrm{M} \mathrm{H}_{2} \mathrm{O}_{2}$ plus $5 \mu \mathrm{M}$ DTT. DTT treatment alone show comparable effects to $\mathrm{H}_{2} \mathrm{O}_{2}$ treatments. The arrows indicate the typical length showing the distance travelled by RAP motile sperm cell (red arrow) and progressive motility (green arrow), bar $=25 \mu \mathrm{m}$.

presence of DTT, $50 \mu \mathrm{M} \mathrm{H}_{2} \mathrm{O}_{2}$ induced a decrease in VSL (from $49.3 \pm 11.4$ to $23.5 \pm 8.71$ ), VAP (from $63.63 \pm 17.86$ to $51.07 \pm 11.6$ ), LIN (from $65.05 \pm 11.45$ to $33.1 \pm 11.98$ ), STR (from $77.25 \pm 8.55$ to $44.53 \pm 11.12$ ) and WOB (from 83.55 \pm 5.65 to $72.20 \pm 11.6$ ). The presence of DTT did not improve the Pearson's correlation coefficient of all the semen velocity parameters except for VCL, which indicated a high negative correlation in the presence of DTT $(r=-0.829)$ and a low correlation in the absence of DTT $(r=0.165)$, and VAP which indicated a moderately high correlation in the presence of DTT $(r=0.644)$ and a low correlation in the absence of DTT $(r=0.184)$, plus STR which indicated a high moderate correlation in the presence of DTT $(r=0.791)$ and a low moderate correlation in the absence of DTT $(r=0.424)$. The correlation for the other semen 
velocity parameters were VSL $(r=0.581$ from $r=0.562)$, $\operatorname{lIN}(r=0.446$ from $r=$ $0.489)$ and WOB $(r=0.455$ from $r=0.235)$. In addition, $\mathrm{H}_{2} \mathrm{O}_{2}$ had a low correlation with buck semen apoptosis $(r=0.305)$ while the presence of DTT increased the buck semen apoptosis correlation $(r=0.9886)$ and also the buck semen viability correlation (from $r=0.128$ to $r=0.7299$ ) (Table 4 ).

\section{Discussions}

This study indicates that $\mathrm{H}_{2} \mathrm{O}_{2}$ induces oxidative damage to the South African indigenous unimproved buck semen which is accompanied by changes in the semen velocity parameters, semen motility parameters and semen viability after 3 hours of treatment. Interesting, after 3 hours of $\mathrm{H}_{2} \mathrm{O}_{2}$ treatment there was minimal changes in the $\mathrm{pH}$ which accompanied decreases in cell viability. $\mathrm{H}_{2} \mathrm{O}_{2}$ increased TM but the presence of DTT decreased it, except at $50 \mu \mathrm{M}$ were TM was increased by $20 \%$. In a similar study, Griveau et al. [15] demonstrated that $50 \mu \mathrm{M} \mathrm{H}_{2} \mathrm{O}_{2}$ accelerated the hyperactivation and acrosome reaction of semen after incubation for $3 \mathrm{hrs}$. In this study, at the highest $\mathrm{H}_{2} \mathrm{O}_{2}$ concentration used $(200 \mu \mathrm{M}), \mathrm{PM}$ was increased by $4 \%$. Amazingly, DTT further increases PM of buck semen by a further $16 \%$. For RAP, $\mathrm{H}_{2} \mathrm{O}_{2}$ induced an increase of $4 \%$ above the raw semen RAP value. These observations indicated that buck semen was more robust in dealing with ROS effects on motility parameters, as opposed to boars under similar conditions [12]. This is in agreement with de Lamirande et al. [16] who concluded that, the deleterious effects of ROS on the semen motility parameters, depends on the species being investigated. Also, Sarangi et al. [17] reported that buck semen liquid preserved in tris-based extender in the presence of vitamin E and glutathione antioxidants revealed high PM, viability, acrosome integrity and antioxidant enzymes with low lipid peroxidation.

Also, $200 \mu \mathrm{M} \mathrm{H}_{2} \mathrm{O}_{2}$ increased VCL, VAP, VSL, LIN, STR and WOB in South African indigenous unimproved buck semen. In the presence of DTT, VAP, VSL, LIN, STR and WOB were even further increased but not VCL. Also, semen treated with $200 \mu \mathrm{M} \mathrm{H}_{2} \mathrm{O}_{2}$, DTT had no effect on VCL. The decrease in semen VCL is due to a reduction in both the angle of lateral head displacement (ALH) and the beat cross frequency (BCF). A decrease in ALH means the sperm head is moving less from side to side while a decrease in BCF means these actions occur slower. The VSL is increased by $\mathrm{H}_{2} \mathrm{O}_{2}$ and further increased by DTT. Since VSL is improved, this indicates that the buck semen could still be used for fertilization of an oocytesince increases in VSL is indicative of high semen fertilizing potential, as shown previously in rats [18] and hamsters [19]. VAP was increased even further by DTT in $\mathrm{H}_{2} \mathrm{O}_{2}$ induced semen. Also, $\mathrm{H}_{2} \mathrm{O}_{2}$ had a minimal increase in LIN that was further improved by about $10 \%$ by presence of DTT. STR and WOB were increased by $10 \%$ by $\mathrm{H}_{2} \mathrm{O}_{2}$ and further increased by $18 \%$ in the presence of DTT as compared to buck raw semen values. This data demonstrates that buck semen can resist and remain viable under moderate to high oxidative stress. 


\section{Conclusion}

South African indigenous unimproved buck semen characterisation is currently been addressed and knowledge of their vulnerability to oxidative stress is necessary. Interestingly South African unimproved buck semen shows robust resistance to ROS effects, as shown by improved or unaffected motility and velocity parameters. Currently, in livestock, semen motility parameters are being used as a measure of their fertility potential. In South African unimproved buck semen, fertilizing potential might not be an issue since they show resistance to ROS, however the use of antioxidant should still be considered. While these data show buck semen resistance to ROS, more research is required to investigate how and why buck semen has resistance to ROS as compared to semen from boars.

\section{Acknowledgements}

The authors wish to acknowledge the Agricultural Research Council (ARC) and Department of Forestry and Fisheries (DAFF) for providing necessary facilities and financial support, respectively.

\section{Conflicts of Interest}

The authors declare no conflicts of interest regarding the publication of this paper.

\section{References}

[1] Narwade, B.M., Mohanty, T.K., Bhakat, M. and Rahim, A. (2017) Goat Semen Cryopreservation Using Egg Yolk and Soya Based-Extenders Containing Trehalose. The Indian Journal of Animal Sciences, 87, 851-855.

[2] Purdy, P.H. (2006) A Review on Goat Sperm Cryopreservation. Small Ruminant Research, 63, 215-225. https://doi.org/10.1016/j.smallrumres.2005.02.015

[3] Webb, E.C., Cronje, P.B. and Donkin, E.F., Eds. (1999) Research and Training Strategies for Goat Production Systems in South Africa. Proceedings of a Workshop, Hogsback, 22-26 November 1998.

[4] Visser, C., Hefer, C.A., van Marle-Köster, E. and Kotze, A. (2004) Genetic variation of three commercial and three indigenous goat populations in South Africa. South African Journal of Animal Science, 34, 24-27.

[5] Ramukhithi, F.V., Nedambale, T.L., Sutherland, B. and Lehloenya, K.C. (2011) Cryopreservation of South African Indigenous Goat Semen. African Journal of Biotechnology, 10, 17898-17902.

[6] Bopape, M.A., Lehloenya, K.C., Chokoe, T.C. and Nedambale, T.L. (2015) Comparison of Electro Ejaculator and Artificial Vagina on Semen Collection from South African Indigenous Goat Following Assessment by Computer Aided Sperm Analysis. Open Journal of Animal Sciences, 5, 210-218. https://doi.org/10.4236/ojas.2015.52023

[7] Coyle, C.H., Martinez, L.J., Coleman, M.C., Spitz, D.R., Weintraub, N.L. and Kader, K.N. (2006) Mechanisms of $\mathrm{H}_{2} \mathrm{O}_{2}$-Induced Oxidative Stress in Endothelial Cells. Free Radical Biology and Medicine, 40, 2206-2213. https://doi.org/10.1016/j.freeradbiomed.2006.02.017 
[8] Agarwal, A., Virk, G., Ong, C. and du Plessis, S.S. (2014) Effect of Oxidative Stress on Male Reproduction. The World Journal of Men's Health, 32, 1-17. https://doi.org/10.5534/wjmh.2014.32.1.1

[9] Taylor, K., Roberts, P., Sanders, K. and Burton, P. (2009) Effect of Antioxidant Supplementation of Cryopreservation Medium on Post-Thaw Integrity of Human Spermatozoa. Reproductive BioMedicine, 18, 184-189. https://doi.org/10.1016/S1472-6483(10)60254-4

[10] Ahmadi, S., Bashiri, R., Ghadiri-Anari, A. and Nadjarzadeh, A. (2016) Antioxidant Supplements and Semen Parameters: An Evidence Based Review. International Journal of Reproductive BioMedicine, 14, 729-736. https://doi.org/10.29252/ijrm.14.12.729

[11] Bilodeau, J.F., Blanchette, S., Gagnon, C. and Sirard, M.A. (2001) Thiols Prevent $\mathrm{H}_{2} \mathrm{O}_{2}$-Mediated Loss of Sperm Motility in Cryopreserved Bull Semen. Theriogenology, 56, 275-286. https://doi.org/10.1016/S0093-691X(01)00562-3

[12] Pilane, C.M., Bopape, M.A., Mapeka, M.H. and Netshirovha, T.R. (2016) Assessment of the Susceptibility of Boar Semen to Oxidative Stress. Open Journal of Animal Sciences, 6, 123-130. https://doi.org/10.4236/ojas.2016.62015

[13] Chatiza, F., Mokwena, P.W., Nedambale, T.L. and Pilane, C. (2018) Effect of Antioxidants (Taurine, Cysteine, a-Tocopherol) on Liquid Preserved Kolbroek Boar Semen Characteristics. African Journal of Biotechnology, 17, 65-72. https://doi.org/10.5897/AJB2016.15527

[14] Tuncer, P.B., Bucak, M.N., Sariözkan, S., Sakin, F., Yeni, D., Ciğerci, I.H., Ateşşahin, A., Avdatek, F., Gündoğan, M. and Büyükleblebici, O. (2010) The Effect of Raffinose and Methionine on Frozen/Thawed Angora Buck (Capra Hircus Ancryrensis) Semen Quality, Lipid Peroxidation and Antioxidant Enzyme Activities. Cryobiology, 61, 89-93. https://doi.org/10.1016/j.cryobiol.2010.05.005

[15] Griveau, J.F., Renard, P. and LeLannou, D. (1994) An in Vitro Promoting Role for Hydrogen Peroxide in Human Sperm Capacitation. International Journal of Andrology, 17, 300-307. https://doi.org/10.1111/j.1365-2605.1994.tb01260.x

[16] De Lamirande, E., Jiang, H., Zini, A., Kodama, H. and Gagnon, C. (1997) Reactive Oxygen Species and Sperm Physiology. Reviews of Reproduction, 2, 48-54. https://doi.org/10.1530/ror.0.0020048

[17] Sarangi, A., Singh, P., Virmani, M., Yadav, A.S., Sahu, S., Ajithakumar, H.M., Kumari, A. and Rath, A.P. (2017) Effect of Antioxidants Supplementation on the Quality of Beetal Buck Semen Stored at $4^{\circ}$ C. Veterinary World, 10, 1184-1188. https://doi.org/10.14202/vetworld.2017.1184-1188

[18] Moore, H.D.M. and Aknondi, M.A. (1996) Fertilising Capacity of Rat Spermatozoa Is Correlated with Decline in Straight-Line Velocity Measured by Continuous Computer-Aided Sperm Analysis: Epididymal Rat Spermatozoa from the Proximal Cauda Have a Greater Fertilising Capacity in Vitro than Those from the Distal Cauda or Vas Deferens. Journal of Andrology, 17, 50-60.

[19] Slott, V., Jeffay, S.C., Suarez, J.D., Barbee, R. and Perreault, S. (1995) Synchronous Assessment of Sperm Motility and Fertilizing Ability in the Hamster Following Treatment with Chlorohydrin. Journal of Andrology, 16, 523-535. 